\title{
Overexpression of DNA damage-induced $45 \alpha$ gene contributes to esophageal squamous cell cancer by promoter hypomethylation
}

\author{
Bao xiang Wang ${ }^{1}$, Bang Liang Yin ${ }^{1}$, Bin He ${ }^{1}$, Chen Chen ${ }^{1}$, Ming Zhao ${ }^{2}$, Wei xing Zhang ${ }^{3}$, Zhen Kun Xia ${ }^{1}$, \\ Yi zhi Pan ${ }^{4}$, Jing qun Tang ${ }^{1}$, Xin min Zhou ${ }^{1}$ and Ni Yin ${ }^{1 *}$
}

\begin{abstract}
Background: Environmental factors-induced dysfunction of esophageal squamous epithelium, including genomic DNA impairment and apoptosis, play an important role in the pathogenesis of esophageal squamous cell cancer. DNA damage-induced $45 \alpha$ (GADD45 $\alpha$ ) has been found promoting DNA repair and removing methylation marker, Therefore, in this study we will investigate whether GADD45 $\alpha$ expression is induced and its mechanism in esophageal squamous cell cancer.
\end{abstract}

Methods: Two human esophageal squamous cell lines (ESCC), ECA109 and KYSE510 were cultured in RPMI-1640 medium supplemented with 10\% fetal bovine serum (FBS). Lipofectamine 2000 was used to transfect cells. mRNA level of GADD45 $\alpha$ was measured by reverse transcription-quantitive PCR (RT-qPCR), protein level of GADD45 $\alpha$ was detected by western blot and Immunohistochemistry. Global DNA methylation of tissue sample was measured using the Methylamp Global DNA Methylation Quantification Ultra kit (Epigentek Group) and promoter methylation was measured by bisulfite sequencing.

Results: GADD45a mRNA and protein levels were increased significantly in tumor tissue than that in adjacent normal tissue. Hypomethylation of global genomic DNA and GADD45 $\alpha$ promoter were found in ESCC. The cell sensitivity to Cisplatin DDP was decreased significantly in Eca109 and Kyse510 cells, in which GADD45 $\alpha$ expression was down-regulated by RNA interference (RNAi). In addition, silence of GADD45a expression in ESCC cells inhibited proliferation and promoted apoptosis.

Conclusion: Overexpression of GADD45 $\alpha$ gene is due to DNA hypomethylation in ESCC. GADD45 $\alpha$ may be a protective factor in DDP chemotherapy for esophageal squamous cell carcinoma.

Keywords: Esophageal squamous cell cancer, GADD45a, DNA methylation, DNA damage

\section{Background}

Esophageal cancer is the eighth most common malignancy and the sixth most common cause of cancerrelated death worldwide [1,2], its prevalence and death rate are continuously increasing and thus has become a major health concern[3]. Esophageal squamous cell carcinoma (ESCC) is the predominant type of esophageal cancer, comprising almost $95 \%$ of cases. The development of ESCC is strongly correlated with a number of

\footnotetext{
* Correspondence: wangbaoxiang615@sohu.com

'Department of cardiothoracic Surgery, Second Xiangya Hospital of Central

South University, Changsha, Hunan, PR China

Full list of author information is available at the end of the article
}

dietary and environmental factors, such as alcohol consumption, smoking, hot food, pungent meal and high levels of nitrates in the soil and drinking water [4]. These pathogenic factors may destroy esophageal squamous epithelium, thus epithelial cells suffer from DNA damage and apoptosis [5], which may result in genomic instability and cell transformation. Although multiple genetic and epigenetic changes have been reported in ESCC development and progression [6-15], the precise molecular mechanisms still remain unclear.

Growth arrest and DNA damage-induced $45 \alpha$ (GADD45 $\alpha$ ), a nuclear protein, belongs to the DNA damage-induced 45 family, has been considered to 
participate in cellular response to a variety of DNA damage agents. GADD $45 \alpha$-null mice generated by gene targeting exhibits severe genomic instabilities [16]. Most strikingly, mice lacking the GADD $45 \alpha$ gene are susceptible to DNA damage-induced tumors, including carcinogenesis induced by ionizing radiation, UV radiation and dimethylbenzanthracene (DMBA) $[17,18]$. A recent study showed that GADD $45 \alpha$ has a key role in active DNA demethylation and its overexpression activates methylation-silenced reporter plasmids and promotes global DNA demethylation. [19]

DNA methylation in cancer tissue was first observed more than two decades ago[20] and may be linked to carcinogenesis[21].The in-depth investigations of the relationship between DNA methylation and gene expression provide very important information for understanding cancer and finding the effective therapy strategy. Presently, GADD $45 \alpha$ expression and promoter methylation status in ESCC have not been reported. We hypothesized that epigenetic regulation on GADD $45 \alpha$ may play an important role in ESCC development.

In this study, we first detected GADD $45 \alpha$ mRNA expression by reverse transcription- quantitative polymerase chain reaction (RT-qPCR) and DNA methylation status by bisulfite sequence in 40 primary ESCC tissues and corresponding normal tissues. We further evaluated the correlations among GADD $45 \alpha$ mRNA, DNA methylation and the tumor clinical pathologic stages. RNAi was subsequently applied to investigate the role of GADD $45 \alpha$ on cell proliferation and apoptosis in esophageal squamous cancer cell line.

\section{Methods \\ Samples}

Tumor tissue and adjacent normal tissue(confirmed by hematoxylin and eosin) were obtained from 40 esophageal squamous cell cancer patients(Table 1) who underwent curative resection at the second Xiang Ya Hospital (Hunan, China) between June 2010 and January 2011 after informed consent was obtained from all the patients. None of the patients received chemotherapy and radiotherapy before surgery. Tissues were fixed in $10 \%$ buffered formaldehyde solution for pathological diagnosis and imunohistochemical staining and frozen in liquid nitrogen for DNA, RNA and protein isolation.

\section{Cell lines}

Two human esophageal squamous cell lines, ECA109 and KYSE510 were obtained from American Type Culture Collection (ATCC) and Deutsche Sammlung von Mikroorganismen und Zellkulturen GmbH (German Collection of Microorganisms and Cell Cultures)
Table 1 Clinical character of ESCC patients

\begin{tabular}{|c|c|c|}
\hline $\begin{array}{l}\text { Patient/age/ } \\
\text { sex }\end{array}$ & $\mathrm{T} / \mathrm{N} / \mathrm{M} / \mathrm{G}$ & $\begin{array}{l}\text { Condition of one year after } \\
\text { operation }\end{array}$ \\
\hline $1 / 64 / \mathrm{M}$ & $\begin{array}{l}\text { T3/N1b/M0/G1- } \\
\text { G2 }\end{array}$ & alive \\
\hline 2/68/M & T3/N0/M0/G1 & alive \\
\hline $3 / 58 / \mathrm{M}$ & $\mathrm{T} 3 / \mathrm{N} 0 / \mathrm{M} 0 / \mathrm{G} 1$ & alive \\
\hline $4 / 61 / \mathrm{M}$ & TO/N0/M0/G1 & alive \\
\hline 5/63/M & $\mathrm{T} 1 \mathrm{~b} / \mathrm{N} 0 / \mathrm{M} 0 / \mathrm{G} 2$ & alive \\
\hline 6/76/F & $\mathrm{T} 2 / \mathrm{N} 0 / \mathrm{MO} / \mathrm{G} 3$ & alive \\
\hline $7 / 62 / \mathrm{M}$ & T3/N1a/M0/G1 & alive \\
\hline $8 / 55 / \mathrm{M}$ & T3/N1a/M0/G2 & alive \\
\hline $9 / 63 / M$ & $\mathrm{~T} 2 / \mathrm{N} 1 \mathrm{a} / \mathrm{M} 0 / \mathrm{G} 2$ & alive \\
\hline 10/47/M & $\mathrm{T} 2 / \mathrm{N} 1 \mathrm{a} / \mathrm{M} 0 / \mathrm{G} 1$ & alive \\
\hline $11 / 42 / M$ & T2/NO/MO/G2 & alive \\
\hline $12 / 55 / M$ & T3/N0/M0/G1 & alive \\
\hline $13 / 56 / \mathrm{M}$ & $\begin{array}{l}\mathrm{T} 1 \mathrm{~b} / \mathrm{N} 0 / \mathrm{M} 0 / \mathrm{G} 1- \\
\mathrm{G} 2\end{array}$ & alive \\
\hline 14/56/M & $\mathrm{T} 3 / \mathrm{N} 1 \mathrm{a} / \mathrm{M} 0 / \mathrm{G} 1$ & dead \\
\hline 15/73/M & $\begin{array}{l}\text { T4/N0/M1/G2- } \\
\text { G3 }\end{array}$ & alive \\
\hline 16/61/M & T3/N0/M0/G2 & alive \\
\hline $17 / 67 / M$ & $\mathrm{~T} 2 / \mathrm{N} 0 / \mathrm{MO} / \mathrm{G} 2$ & alive \\
\hline $18 / 59 / M$ & $\mathrm{~T} 2 / \mathrm{N} 1 \mathrm{a} / \mathrm{M} 0 / \mathrm{G} 2$ & alive \\
\hline 19/55/M & T3/N1b/M0/G2 & alive \\
\hline $20 / 58 / M$ & T3/N1a/M0/G2 & alive \\
\hline $21 / 57 / M$ & $\mathrm{~T} 2 / \mathrm{N} 1 \mathrm{a} / \mathrm{M} 0 / \mathrm{G} 2$ & alive \\
\hline $22 / 65 / M$ & $\begin{array}{l}\text { T2/N1a/M0/G2- } \\
\text { G3 }\end{array}$ & metastasis in lymph node of nest \\
\hline $23 / 54 / M$ & T3/N1a/M0/G2 & alive \\
\hline $24 / 56 / M$ & T3/N0/M0/G2 & alive \\
\hline 25/74/M & T2/N1a/M0/G2 & metastasis in lymph node of nest \\
\hline 26/51/M & T2/N1b/Mo/G1 & alive \\
\hline 27/52/M & T3/N1a/M0/G1 & alive \\
\hline $28 / 60 / M$ & $\mathrm{~T} 2 / \mathrm{N} 1 \mathrm{a} / \mathrm{M} 0 / \mathrm{G} 2$ & alive \\
\hline $29 / 47 / M$ & T2/N0/MO/G2 & alive \\
\hline $30 / 55 / M$ & $\mathrm{~T} 3 / \mathrm{N} 1 \mathrm{~b} / \mathrm{M} 0 / \mathrm{G} 2$ & alive \\
\hline $31 / 68 / M$ & T3/N0/M0/G2 & alive \\
\hline $32 / 71 / M$ & $\mathrm{~T} 3 / \mathrm{N} 1 \mathrm{a} / \mathrm{M} 0 / \mathrm{G} 2$ & alive \\
\hline 33/55/M & T2/N0/M0/G1 & alive \\
\hline $34 / 69 / \mathrm{M}$ & $\mathrm{T} 2 / \mathrm{N} 0 / \mathrm{MO} / \mathrm{G} 2$ & alive \\
\hline $35 / 55 / M$ & $\mathrm{~T} 2 / \mathrm{N} 1 \mathrm{~b} / \mathrm{M} 0 / \mathrm{G} 2$ & alive \\
\hline $36 / 59 / M$ & $\begin{array}{l}\text { T2/N1b/M0/G1- } \\
\text { G2 }\end{array}$ & metastasis in liver \\
\hline $37 / 60 / M$ & T2/N0/M0/G2 & alive \\
\hline $38 / 54 / M$ & $\mathrm{~T} 2 / \mathrm{N} 1 \mathrm{a} / \mathrm{M} 0 / \mathrm{G} 2$ & alive \\
\hline $39 / 62 / M$ & T3/N1b/M0/G2 & alive \\
\hline 40/59/M & $\begin{array}{l}\mathrm{T} 1 \mathrm{~b} / \mathrm{N} 0 / \mathrm{M} 0 / \mathrm{G} 1- \\
\mathrm{G} 2\end{array}$ & alive \\
\hline
\end{tabular}


(DSMZ) respectively, and were grown in Hyclone RPMI1640 medium (Thermo scientific, Beijing, China) supplemented with $10 \%$ fetal bovine serum (FBS), $100 \mathrm{U} / \mathrm{ml}$ of penicillin sodium, and $100 \mathrm{mg} / \mathrm{ml}$ of streptomycin sulfate, cultured at $37^{\circ} \mathrm{C}$ in humidified air containing $5 \%$ carbon dioxide air atmosphere. HEEpiC(Human esophageal epithelial cells) cell line was obtained from San Diego, US (ScienCell). And they were cultured and proliferated in Epithelila Cell Medium- 2 at $37^{\circ} \mathrm{C}$ in humidified air containing 5\% carbon dioxide air atmosphere.

\section{Real-time reverse transcription-polymerase chain reaction (RT-PCR)}

Total RNA was isolated from tumor and adjacent normal tissue using Trizol reagent according to standard protocol (Invitrogen, USA). cDNA synthesis was performed using RevertAid ${ }^{\mathrm{TM}}$ First Strand cDNA Synthesis Kit (Fermentas, Burlington, Canada) and $1 \mu \mathrm{g}$ of total input RNA according to the manufacturer's instructions. Real-time quantitative PCR was performed using a Rotor-Gene3000 (Corbett Research, NSW, Australia) and mRNA levels were quantified using SYBR Premix Ex TaqTM real-time PCR Kit (TaKaRa Biotech [Dalian] Co., China). $\beta$-actin was also amplified and used as a loading control. The primers for GADD45 $\alpha$, GADD45 $\beta$, GADD $45 \gamma$, and $\beta$-actin used were shown in Table 2.

\section{Bisulfite genomic sequencing}

Bisulfite conversion was performed using the Epitect Bisulfite kit (Qiagen Germany) according to the manufacture's protocol. The 484 bp GADD $45 \alpha$ promoter fragments were amplified using nested PCR, and then cloned into a pGEM-T vector (Promega USA). The 5 independent clones were then sequenced for each of the amplified fragments. The primers for GADD $45 \alpha$ were as follows: first round, forward 5'-TGTGGGCTGTGTGGGTGTCAGATGG-3' and reverse 5'-GAGGGTTGGCAGGATAACCCC-3'; the second round, forward 5'AAAGTTTTTTATTTTTAATGGTTTTT-3' and reverse 5'-GGTTAAATTGTTGGAGTAGGTTGAT-3 ‘.

Table 2 Primers of genes

\begin{tabular}{cc}
\hline Gene & primers \\
\hline GADD45 $\alpha$, & PF:5'-GCCTGTGAGTGAGTGCAGAA-3', \\
\hline RF: 5'-CCCCACCTTATCCATCCTTT-3' \\
\hline PADD55'-TCGGCCAAGTTGATGAATG-3': \\
\hline RF: 5'-CAGAAGGACTGGATGAGCGT-3' \\
\hline PADD 5'-CGTCTACGAGTCAGCCAAAG-3' \\
\hline RP:5'-GCCTGGATCAGCGTAAAAT-3' \\
\hline PF:5'GCACCACACCTTCTACAATGAGC'3 & RP:5'GGATAGCACAGCCTGGATAGCAAC'3
\end{tabular}

\section{Global DNA methylation detection}

Genomic DNA was isolated from tissue of tumor and normal adjacent using the TIANamp Genomic DNA kit (Tiangen Biotech). Global methylation levels were measured using the Methylamp Global DNA Methylation Quantification Ultra kit (Epigentek Group) according to the manufacturer's instruction. In this assay, DNA is immobilized to wells specifically coated with a specific DNA affinity substratum. The methylated fraction of DNA can be recognized with a 5-methylcytosine antibody and quantified through an ELISA-like reaction. Absorbance was measured at $450 \mathrm{~nm}$.

\section{Immunohistochemistry}

The paraffin sections were made from the tumor tissue and adjacent normal tissue of patients. All the paraffin sections were 4 um thick. Firstly the paraffin sections were baked at $60^{\circ} \mathrm{C}$ for $1 \mathrm{~h}$ and were dew axed with turpentine Oil and 100\%, 95\%, 75\% and 50\% alcohol one by one. The sections were incubated in $1.2 \%$ hydrogen peroxide for $10 \mathrm{~min}$ and rinsed in phosphate balanced solution(PBS), $\mathrm{pH} \mathrm{7.4,} \mathrm{for} 12 \mathrm{~min}$. The sections were then blocked for $1 \mathrm{~h}$ with normal goat serum. After incubating with the primary rabbit anti-human antibody for $1 \mathrm{~h}$ at room temperature, the cryostat sections were washed in PBS and incubated with a secondary anti-rabbit biotinylated antibody for $30 \mathrm{~min}$, and subsequently with the streptavidin-HRP complex for $10 \mathrm{~min}$, rinsed in PBS. And then the sections were stained with ACE solution for $10 \mathrm{~min}$. Finally the sections were stained with haematoxylin. The results were analyzed with Point rating method. We used the percentage of GADD45 $\alpha$ positiv stained cells and the intensity of GADD $45 \alpha$ expression by the tumor cells to grade all the samples. And the multiplication of these two grading scores calculates the immunoreactive score for GADD $45 \alpha$ expression (GADD $45 \alpha$-IRS) in stained tissue (\%GADD $45 \alpha$ -positive tumor cells $\times$ staining intensity $=$ GADD $45 \alpha$ IRS).

\section{Western blot analysis}

For tumor and adjacent normal tissues were frozen in liquid nitrogen and powdered with mortar and pestle and lysed by cell lysis buffer. Samples were transferred to microcentrifuge tubes, homogenized, and protein pelleted by microcentrifugation at $14000 \mathrm{rpm}$ and $4^{\circ} \mathrm{C}$ for 15 min. The samples were diluted with $2 \times$ sodium dodecyl sulfate (SDS) sample buffer and boiled. SDS samples were resolved by polyacrylamide gel electrophoresis and transferred onto polyvinylidene difluoride membrane. The membranes were incubated with the primary antibodies and then with horseradish peroxidase-conjugated secondary antibodies. The 
immunoblotted proteins were photographed using Lumiglo Reagent (\#7003, CellSignaling Inc.).

\section{Transfections}

Control small interfering RNA (siRNA) and siRNA targeting GADD45 $\alpha$ were designed and synthesized at Qiagen USA. The sequences of the siRNA for GADD $45 \alpha$ were as follows: target sequence 5'AACATCCTGCGCGTCAGCAAC-3', sense strand5'CAUCCUGCGCGUCAGCAACTT-3', Antisense strand: 5'-GUUGCUGACGCGCAGGAUGTT-3'. Lipofectamine 2000 was used to transfect siRNA and negative control into the two cell lines ECA109 and kyse510.

Total RNA was extracted from esophageal squamous cell cancer tissue, and GADD $45 \alpha$ cDNA was amplified by RT-PCR. The PCR product was doubly digested by $\mathrm{Xbal}$ and Sall, and then recombined into eukaryotic expression vector. Then, pIRES-GFP-GADD45 $\alpha$ was obtained by G418 selection, and then pIRES-GFPGADD45 $\alpha$ and pIRES-GFP were transfected into human esophageal squamous epithelial cells with lipidosomepackaged method. Meanwhile, the transfected cells were selected by G418, and then stable transfected cell lines were obtained.

\section{Drug sensitivity assay}

Cells $\left(1 \times 10^{5} / \mathrm{ml}\right)$ were cultured in 96 cell plates after 1 day of transfectioin. After 1 day of culturing, the cells were treated with various concentrations of cisplatin (DDP). After $24 \mathrm{~h}, 48 \mathrm{~h}$ and $72 \mathrm{~h}$ of treatment, $20 \mathrm{ul}$ MTT (Roche, Mannheim Germany) solution $(2 \mathrm{mg} / \mathrm{ml}$ ) was added to each well, and the plate was then incubated at $37^{\circ} \mathrm{C}$ for $4 \mathrm{~h}$. Absorbance in individual wells was determined at $570 \mathrm{~nm}$ using a micro plate reader (Model 450, Bio-rad, CA). Three independent experiments were carried out for each treatment.

\section{Flow cytometric analysis}

Eca109 and Kyse510 $\left(4 \times 10^{5}\right)$ were seed in 12 -well plates and then were transfected. Transfected Cells were harvested at $24 \mathrm{~h}, 48 \mathrm{~h}$, and $72 \mathrm{~h}$ for flow cytometric analysis. Cells were washed twice with PBS and then incubated with $20 \mathrm{ug} / \mathrm{ml}$ PI, $100 \mathrm{ug} / \mathrm{ml}$ RNase, and $0.1 \%$ triton X-100 in PBS for $30 \mathrm{~min}$ in the dark. The PI stained cells were analyzed for cell cycle distribution and apoptosis by using a FACScalibur instrument (BD bioscience, San Jose, A) equipped with Cell Quest software (Becton Dickinson).

\section{Statistical analysis}

Students's $t$-test for equality of means was used to compare values. Person's correlation coefficient was used to determine the relationship. $P$ values less than 0.05 were considered significant. All analyses were performed with SPSS version 16.0 software.

\section{Results}

Overexpression of GADD45 $\alpha$ in tumor tissue of ESCC

The mRNA expression levels of GADD45 $\alpha$, GADD45 $\beta$, GADD45 $\gamma$ in tumor tissue and adjacent normal tissue from ESCC were detected. GADD45 $\alpha$ mRNA level was higher in tumor tissue than in adjacent normal tissue $(P$ $=0.001$ ) (Figure $1 \mathrm{~A}$ and Table 3). No significant difference was found in GADD45 (Figure $1 \mathrm{~B}$ and Table 3) and GADD45 $\gamma$ (Figure $1 \mathrm{C}$ and Table 3)mRNA levels between tumor and adjacent normal tissue. The overexpression of GADD $45 \alpha$ in tumor tissue of ESCC was confirmed at the protein level using immunohistochemistry (Figure 1E,F and 1G) and western blotting (Figure $1 \mathrm{H})$. GADD $45 \alpha$-positive staining was mainly located in nucleolus of tumor cells with few positive staining in surrounding matrix. To show the statistical discrimination clearly, samples with nuclear GADD45 $\alpha$-IRS $<5$ were classified as GADD45 $\alpha$-negative (Figure 1F), and those with GADD45 $\alpha$-IRS > 5 were classified as GADD $45 \alpha$ positive (Figure 1E), the ratio of GADD45 $\alpha$ positive was higher in tumor tissues than normal tissues (Table 4).

\section{The correlation between GADD45 $\alpha$ mRNA and clinical pathological stages}

We evaluated the correlation between GADD $45 \alpha$ mRNA expressions in the ESCC tissues with clinical pathological stages. We found that the relative GADD45a mRNA level was $1.8672 \pm 1.26732$ in ESCC tissues from clinical stages I. Moreover, in tissues from stages II, III and IV, the relative GADD45a mRNA levels were $4.0800 \pm 1.30220,4.4936 \pm 1.25856$ and $4.3292 \pm$ 2.69446 respectively. (Table 5 and Figure 1D). The presence of lymph node metastasis, and poor differentiation were associated with mRNA expression levels of GADD 45a in ESCC $(P=0.007, P=0.006, P=0.010$ and $P=0.005$, respectively Table 6 ).

\section{Hypomethylation in promoter of GADD45 $\alpha$ in ESCC}

We detected the methylation status of CG pairs in 181 bp (position-190 to -165) of GADD45 $\alpha$ gene. Amplified fragments were cloned and five clones were sequenced for each amplification product from each subject. Figure $2 \mathrm{~A}$ and $\mathrm{B}$ show the average methylation of each 11 CG pairs within the promoter region. The mean methylation status of most CG pairs was decreased in the tumor group; there were statistically significant difference in the overall combined mean methylation status between two groups $(0.0545 \pm 0.03067$ vs $0.0255 \pm 0.01788, P=$ 0.000). (Figure 2C). 

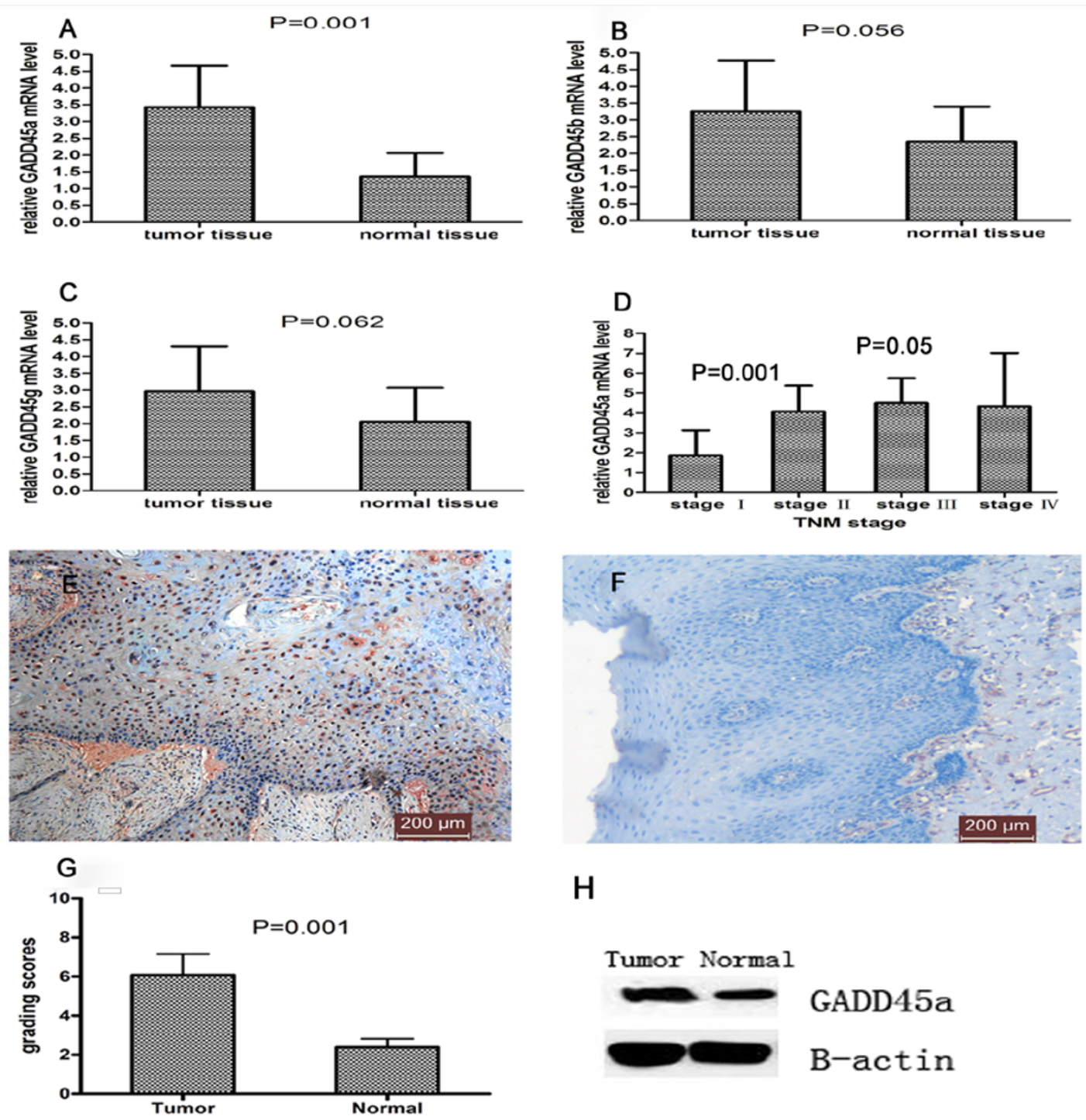

$\mathrm{H}$

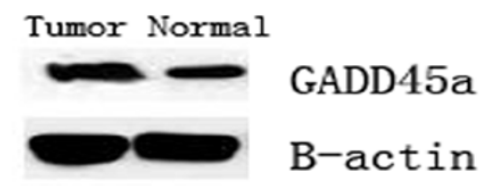

Figure 1 Growth arrest and DNA damage-induced 45a (GADD45 $\alpha$ ), GADD45 $\beta$, GADD45 $\gamma$ gene expression in tumor tissue compared with adjacent normal tissue from the same esophageal squamous cancer patients. A, B and C, Relative expression of GADD45a, GADD45 $\beta$, GADD45 $\gamma$ mRNA in tumor tissues from ESCC patients was measured by quantitative real-time PCR. Results were normalized to the level of $\beta$ actin (loading control). D shows the different expression levels of GADD45 $\alpha$ in various TNM stages. G. Protein levels of GADD45 $\alpha$ in tumor tissue and adjacent normal tissue from ESCC patients were assessed by immunohistochemistry. E shows the representative GADD45 $\alpha$-positive staining in tumor tissue from ESCC patients. GADD45 $\alpha$ protein is mainly located in nucleolus of tumor cells. F. Negative control with less GADD45 $\alpha$ staining in normal tissue. H Protein levels of GADD45 $\alpha$ in tumor tissue and adjacent normal tissue from ESCC patients were assessed by western blotting.

\section{Global DNA hypomethylation in ESCC and its correlation} with clinical pathological stages

We compared the level of global DNA methylation in tumor with normal adjacent tissue. And it was found that the global DNA methylation level was significantly lower in tumor than normal adjacent tissue (Figure 2D). By evaluating the correlation between global DNA methylation level in the ESCC tissues and clinical pathological stages. We found global DNA methylation levels were higher in stages I and II than that in III and IV stages. And the same correlation was found between global DNA methylation and lymph node metastasis. A significant correlation between global DNA methylation level and clinical pathological stages was observed $(P<0.05)$ (Table 7$)$.

\section{GADD45a-siRNA transfection decreased the expression of GADD45a mRNA and protein}

The levels of GADD $45 \alpha$ mRNA and protein were detected at $48 \mathrm{~h}$ after transfection by RT-qPCR and western blot. The levels of GADD $45 \alpha$ mRNA and 
Table 3 Relative mRNA level

\begin{tabular}{cccc}
\hline Gene & tumor & normal tissue & $\boldsymbol{P}$ value \\
\hline GADD45 $\alpha$ & $3.4315 \pm 1.2301$ & $1.3524 \pm 0.7102$ & 0.001 \\
\hline GADD45 $\beta$ & $3.2564 \pm 1.5201$ & $2.3472 \pm 1.0526$ & 0.056 \\
\hline GADD45 $\gamma$ & $2.9562 \pm 1.3458$ & $2.0561 \pm 1.0210$ & 0.062 \\
\hline
\end{tabular}

protein were decreased significantly in GADD $45 \alpha$ knocking-down group (Figure 3A,B,C).

\section{Depletion of GADD45a in ESCC cells inhibited} proliferation and promoted apoptosis

We observed the proliferation and apoptosis of Eca109 and Kyse 510 at $24 \mathrm{~h}, 48 \mathrm{~h}$ and $72 \mathrm{~h}$ after transfection. And we found that cell proliferation of ESCC cells with GADD45 $\alpha$-siRNA were decreased (Figure 4A and B and Table 8) significantly. In contrast, the percentage of apoptosis cells was increased in ESCC cells with GADD45 $\alpha$-siRNA than negative control (Figure $4 \mathrm{C}$ and 4D and Table 9).

\section{Decreased GADD45 $\alpha$ expression by gene silence down regulated the sensitivity of Eca109 and Kyse510 cells to DDP}

We detected the sensitivity of Eca109 and Kyse510 cells transfected with GADD $45 \alpha$-siRNA to Cisplatin (DDP) at $24 \mathrm{~h}, 48 \mathrm{~h}$ and $72 \mathrm{~h}$ after treatment with DDP, at different concentration $(0.5 \mathrm{ug} / \mathrm{ml}$ and $1 \mathrm{ug} / \mathrm{ml})$ [22]. As shown in Figure 5, we observed a decreased sensitivity of Eca109 and Kyse510 cells to DDP dependent of time and dose of GADD45 $\alpha$-siRNA transfection in the group with knock-down GADD45 $\alpha$ (Figure 5A,B,C,D).

\section{The relation of GADD45a and global DNA methylation}

The level of global DNA methylation was detected in the group of GADD45a-siRNA and NC-siRNA respectively. Then the result was that GADD45a-siRNA transfection increased global DNA methylation (Figure 6A and 6B).By making GADD45a overexpressed in normal human esophageal epithelial cells, it was found that the overexpression of GADD45a decreased global DNA methylation (Figure 6C).

\section{Conclusions}

Overexpresssion and promoter hypomethylation of GADD $45 \alpha$ gene and global DNA hypomethylation were found in ESCC tissues, which provide evidence that promoter hypomethylation may be the major mechanism

Table 4 The result of immunohistochemistry

\begin{tabular}{lll}
\hline Tissue & GADD45 $\boldsymbol{\alpha}-$ IRS $>\mathbf{5}$ & GADD45 $\boldsymbol{\alpha}-$ IRS $<\mathbf{5}$ \\
\hline Tumor & $18 / 20$ & $2 / 20$ \\
\hline Normal & $0 / 20$ & $20 / 20$ \\
\hline
\end{tabular}

Table 5 Correlation between the expression level of GADD45 $\alpha$ mRNA and pTNM staging

\begin{tabular}{cllll}
\hline TNM stage & Relative GADD45a mRNA & \multicolumn{3}{c}{$P$ value } \\
\hline I & $1.8672 \pm 1.26732$ & $0.026^{\mathrm{a}}$ & $0.031^{\mathrm{b}}$ & $0.029^{\mathrm{c}}$ \\
\hline II & $4.0800 \pm 1.30220$ & $0.082^{\mathrm{d}}$ & $0.091^{\mathrm{e}}$ & \\
\hline III & $4.4936 \pm 1.25856$ & $0.90^{\mathrm{f}}$ & & \\
\hline IV & $4.3292 \pm 2.69446$ & & &
\end{tabular}

${ }^{a}$ was the result of compare between stage I and II. ${ }^{b}$ was the result of compare between stage land III. ${ }^{c}$ was the result of compare between stage land IV. ${ }^{\mathrm{d}}$ was the result of compare between stage Iland III. ${ }^{\mathrm{e}}$ was the result of compare between stage II and IV. $f$ was the result of compare between stage III and IV

for activating GADD45 $\alpha$ gene in ESCC. The function of GADD $45 \alpha$ in cell proliferation and apoptosis further demonstrated that overexpression of GADD $45 \alpha$ contributes to the development of ESCC.

\section{Discussion}

GADD45 $\alpha$, a nuclear protein, is implicated in the maintenance of genomic stability probably by controlling cell cycle G2-M checkpoint $[18,23]$, induction of cell death [24], and DNA repair process [25-27]. It has been documented that GADD $45 \alpha$ promotes gene activation by repair-mediated DNA demethylation[19]. As DNA repair gene, GADD45 $\alpha$ is involved in the pathogenesis of many kinds of human cancers [28]. Recently, Zhang et al. reported that GADD $45 \alpha$ play an essential role in gene-specific active DNA demethylation during adult stem cell differentiation [29]. But there is no report about expression and DNA methylation status of GADD $45 \alpha$ gene and its role in ESCC. In this study, increased GADD45 $\alpha$ expression was observed in esophageal squamous cancer tissues, and overexpression of GADD $45 \alpha$ gene was associated with lymph node metastasis, and poor differentiation and TNM staging of ESCC. Hypomethylation in promoter of GADD45 $\alpha$ and global DNA hypomethylation in tumor tissues of ESCC was also identified.

Table 6 Correlation between the expression level of GADD45 $\alpha$ mRNA and clinic pathological factors

\begin{tabular}{cccc}
\hline & Total & Relative GADD45a mRNA & $P$ \\
\hline \multicolumn{2}{l}{ Depth of invasion } & & \\
\hline T1/2 & 23 & $2.1683 \pm 1.06534$ & 0.007 \\
\hline T3/4 & 17 & $4.0265 \pm 1.20145$ & \\
\hline Lymph node metastasis & & \\
\hline N0 & 18 & $1.5682 \pm 0.76238$ & $0.006 \mathrm{a}$ \\
\hline N1 & 14 & $3.8326 \pm 1.25123$ & $0.010 \mathrm{~b}$ \\
\hline N2/N3 & 8 & $4.8352 \pm 1.81245$. & $0.005 \mathrm{C}$ \\
\hline
\end{tabular}

${ }^{a}$ was the result of compare between $\mathrm{N} 0$ and $\mathrm{N} 1 .{ }^{\mathrm{b}}$ was the result of compare betweenN1 and N2/N3

c was the result of compare between stage N0 and N2/N3 

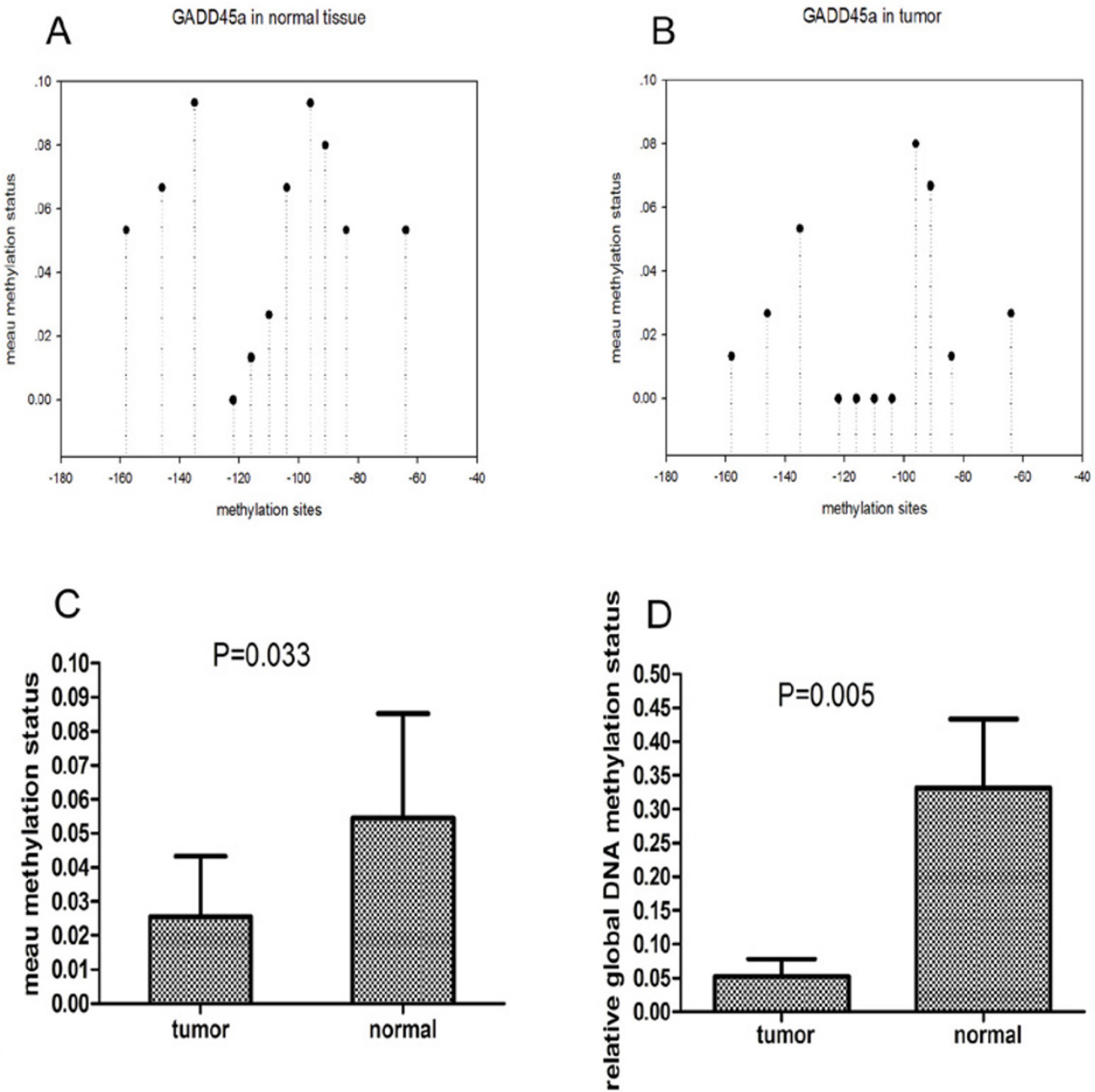

Figure $2 \mathrm{~A}$ and $\mathrm{B}$ show the mean methylation status of each CG pairs in the promoter region upstream of GADD45 $\alpha$ gene in tumor tissue and adjacent normal tissue. Compared with adjacent normal tissue, the promoter region with 11 CG pairs $(-158,-146,-135,-122,-116,-$ $110,-104,-96,-91,-84$, and-64 bp) upstream of GADD45 $\alpha$ gene were hypomethylation in tumor tissue. C, the average methylation levels of CpG pairs in the region (-190 to-10 bp) of GADD45 $\alpha$ promoter is significantly decreased in tumor tissue compared to the adjacent normal tissue. D shows the global DNA methylation levels of tumor and adjacent normal tissue. Compared with adjacent normal tissue, the global DNA methylation level in tumor tissue is lower.

Table 7 Correlation between the relative global DNA methylation and clinic pathological factors

\begin{tabular}{|c|c|c|c|}
\hline & Total & Relative global DNA methylation & $P$ \\
\hline \multicolumn{4}{|c|}{ Depth of invasion } \\
\hline $\mathrm{T} 1 / 2$ & 23 & $0.5612 \pm 0.0238$ & 0.017 \\
\hline $\mathrm{T} 3 / 4$ & 17 & $0.2535 \pm 0.0176$ & \\
\hline \multicolumn{4}{|c|}{ Lymph node metastasis } \\
\hline NO & 18 & $0.5852 \pm 0.0185$ & $0.026 a$ \\
\hline $\mathrm{N} 1$ & 14 & $0.3536 \pm 0.0152$ & $0.018 \mathrm{~b}$ \\
\hline $\mathrm{N} 2 / \mathrm{N} 3$ & 8 & $0.1568 \pm 0.0123$ & $0.006 \mathrm{c}$ \\
\hline
\end{tabular}

a was the result of compare between $\mathrm{N} 0$ and $\mathrm{N} 1 .{ }^{\mathrm{b}}$ was the result of compare betweenN1 and N2/N3

${ }^{c}$ was the result of compare between stage N0 and N2/N3
In our study, GADD45 $\alpha$ mRNA and protein expressed higher in tumor tissue than in adjacent normal tissue, which may be due to DNA damage in epithelial cells induced by injury of esophageal squamous epithelium. When DNA damage takes place, GADD45 $\alpha$ may act as a player in nucleotide excision repair $[25,30]$. Reinhardt, $\mathrm{H}$. C et al. [31]found that following DNA damage, the p38/MK2 complex delocalized from nucleus to cytoplasm to stabilize GADD $45 \alpha$ mRNA and MK2 phosphorylated PARN, blocking GADD45 $\alpha$ mRNA degradation. Most DNA damaging agents and growth arrest signals (designated as non-IR treatments) have been found to induce GADD $45 \alpha$ in cells regardless of p53 status [30]. GADD45 $\alpha$ induction following DNA 

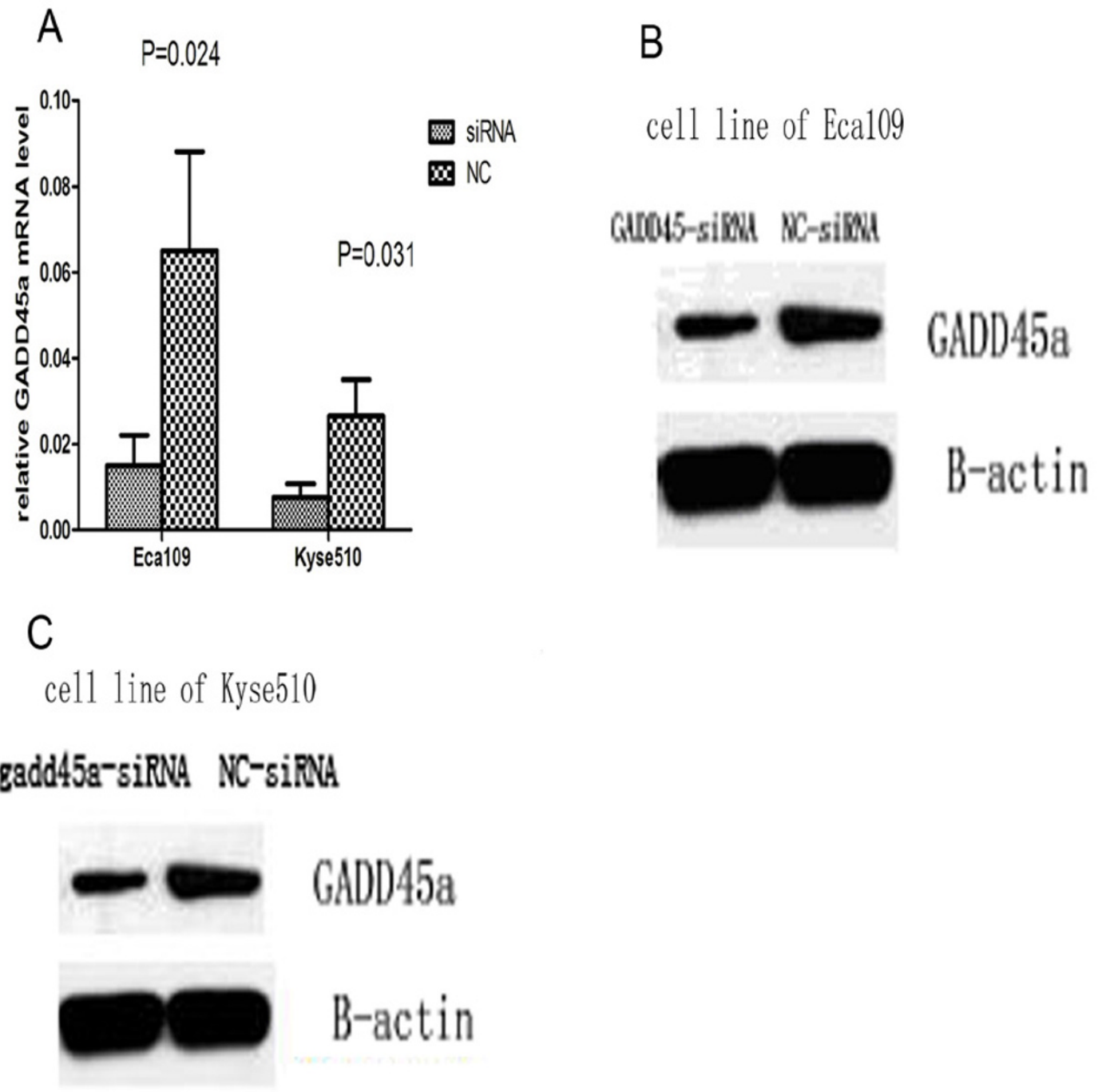

Figure 3 mRNA and protein levels of GADD45 $\alpha$ were detected by real-time PCR and western blot in ECA109 and KYSE510 with siRNAGADD45 $\alpha$ transfection. A,B and C show mRNA and protein expression was inhibited significantly in ECA109 and KYSE510 transfected with siRNA-GADD45 $\alpha$ compared with negative control.

damage is rapid, transient and dose-dependent [32]. GADD $45 \alpha$ induction by certain DNA damage-agents has been detected in a variety of mammalian cells. For example, rapid induction of GADD45 $\alpha$ after MMS and UV treatments has been observed in every cell type tested to date. These cells include multiple mouse cell lines, human fibroblast, human lymphoblast and multiple human tumor lines $[33,34]$. Above all, GADD45 $\alpha$ participated in DNA damage repair process; in return, DNA damage induced its overexpression.

DNA methylation is a major epigenetic mechanism for gene silencing and genome stability in many organisms $[1,35,36]$. In order to investigate the role of GADD $45 \alpha$ in activating DNA demethylation, we explored the global DNA methylation condition and found global DNA hypomethylation in tumor tissues of ESCC. This finding was consistent with the published studies demonstrating incresed global DNA demethylation through GADD $45 \alpha$ overexpression and DNA hypermethylation by scilencing GADD45 $\alpha$ gene.[19]. Global DNA hypomethylation is considered as a feature of tumorigenic cells [37-39]; it can cause chromosomal instability, reactivation of transposable elements, and loss of imprinting $[37,38,40]$. In the experiment, we also found promoter hypomethylation of GADD $45 \alpha$ in tumor tissues. Promoter hypomethylation has been hypothesized to lead to carcinogenesis by encouraging genomic instability [41] as well as by aberrant activation 
A
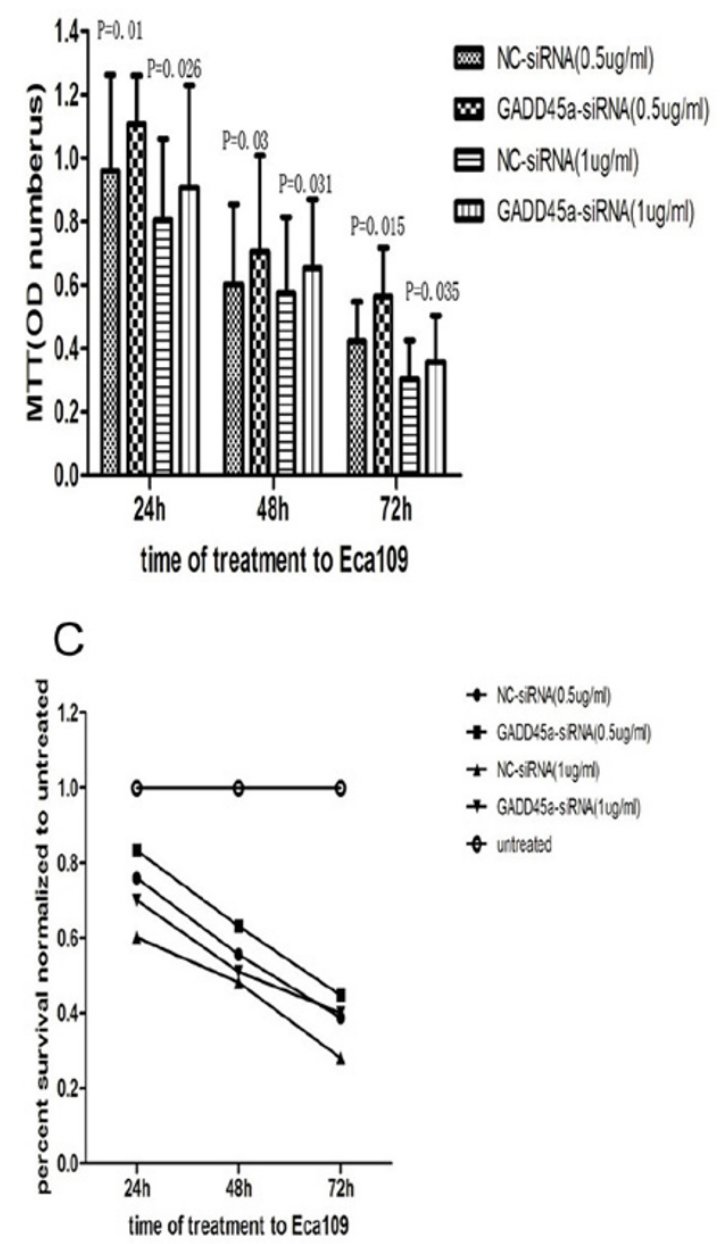

B
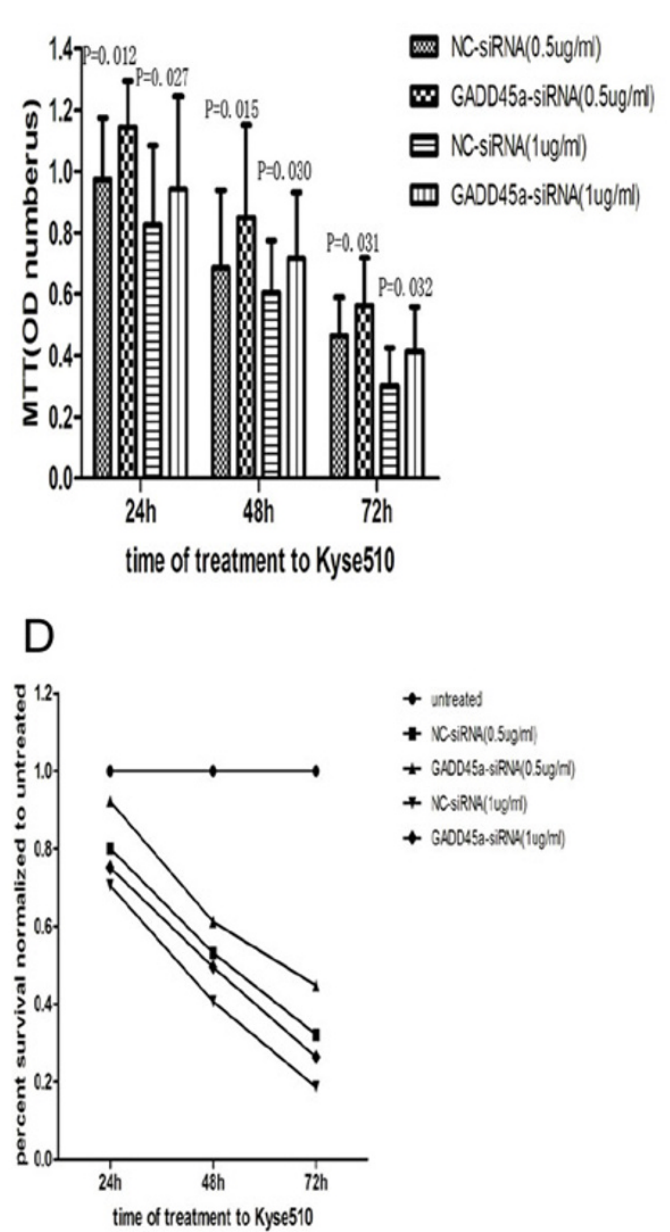

Figure $4 \mathrm{~A}$ and $\mathrm{B}$ show that the ability of cell proliferation in GADD45 $\alpha$-siRNA group was decreased compared with NC-siRNA cells group. $C$ and D show the percentage of apoptotic cells in GADD45 $\alpha$-siRNA group and NC-siRNA group. Results confirmed that cells of apoptosis were increased significantly in the group of siRNA -GADD45 $\alpha$ than in the group of NC-siRNA.

of oncogenes[42], thus promoter hypomethylation may participate in the development of ESCC.

We next investigated the biological effect of GADD45 $\alpha$ in Eca109 and Kyse510 cell lines, and found that depletion of GADD $45 \alpha$ by RNAi inhibited cell proliferation and promoted apoptosis. GADD $45 \alpha$ play a role in the control of the cell cycle G2-M checkpoint. Takekawa et al. have reported that GADD $45 \alpha$ interacts with MEKK4/MTK1 and activates the JNK/p38 signaling pathway that induces apoptosis and introduction of the GADD $45 \alpha$ expression vector into tumor cells via transient transfection induces apoptosis [43]. GADD45 $\alpha$ mediated $\mathrm{JNK} / \mathrm{p} 38$ activation is required for BRCA1induced apoptosis [44] and UVB radiation-induced apoptosis is deficient in GADD45 $\alpha$-/- mouse epidermis [17]. In this study, our results showed that depletion of

Table 8 The ratio of cells in S period

\begin{tabular}{lllllll}
\hline & \multicolumn{3}{c}{ GADD45s-siRNA } & \multicolumn{2}{c}{ NC-siRNA } \\
\hline Eca109 & $\mathbf{2 4} \mathbf{h}$ & $\mathbf{4 8} \mathbf{h}$ & $\mathbf{7 2} \mathbf{h}$ & $\mathbf{2 4} \mathbf{h}$ & $\mathbf{4 8} \mathbf{h}$ & $\mathbf{7 2} \mathbf{h}$ \\
\hline Kyse510 & $47.84 \pm 14.30$ & $32.25 \pm 11.27$ & $25.00 \pm 12.01$ & $51.11 \pm 16.00$ & $42.50 \pm 14.00$ & $31.05 \pm 13.25$ \\
\hline
\end{tabular}


Table 9 The percent of cell in apoptosis

\begin{tabular}{lllllll}
\hline & \multicolumn{3}{c}{ GADD45s-siRNA } & & \multicolumn{2}{c}{ NC-siRNA } \\
\hline Eca109 & $\mathbf{2 4} \mathbf{h}$ & $\mathbf{4 8} \mathbf{h}$ & $\mathbf{7 2} \mathbf{h}$ & $\mathbf{2 4} \mathbf{h}$ & $\mathbf{4 8} \mathbf{h}$ & $\mathbf{7 2} \mathbf{h}$ \\
\hline Kyse510 & $27.33 \pm 12.11$ & $19.00 \pm 2.49$ & $9.00 \pm 2.10$ & $20.50 \pm 8.83$ & $13.41 \pm 7.81$ & $7.00 \pm 4.01$ \\
\hline
\end{tabular}

GADD $45 \alpha$ by RNAi inhibited ESCC cells proliferation and promoted apoptosis, which suggested that GADD45 $\alpha$ may be a novel and effective target for ESCC therapy.

Cisplatin (DDP) is the frequently-used chemotherapeutic agent shown to improve survival in patients with ESCC, as established by randomized controlled trials and therefore approved by the Food and Drug Administration for this use [45-48]. Resistance to chemotherapy, especially to DDP, has presented itself as a major obstacle in treatment of advanced ESCC. Many reports demonstrates that disruption of the apoptotic pathway seems to be a major mechanism of uncontrolled cell proliferation as well as resistance to chemotherapeutic

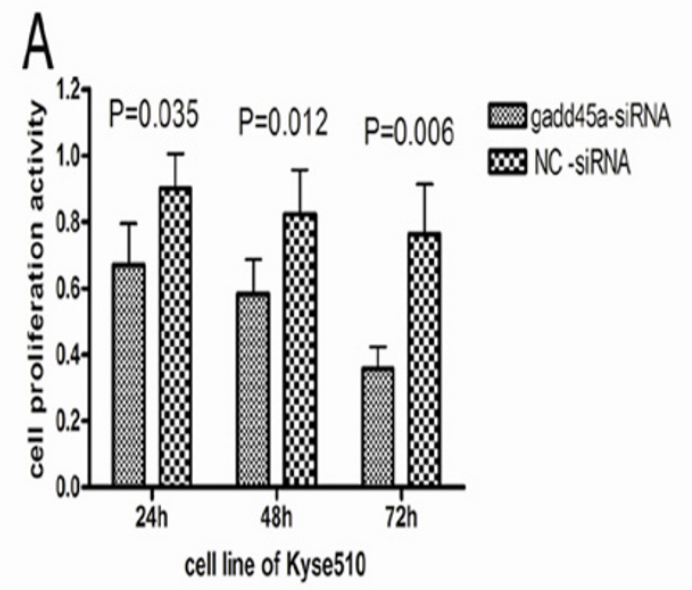

B
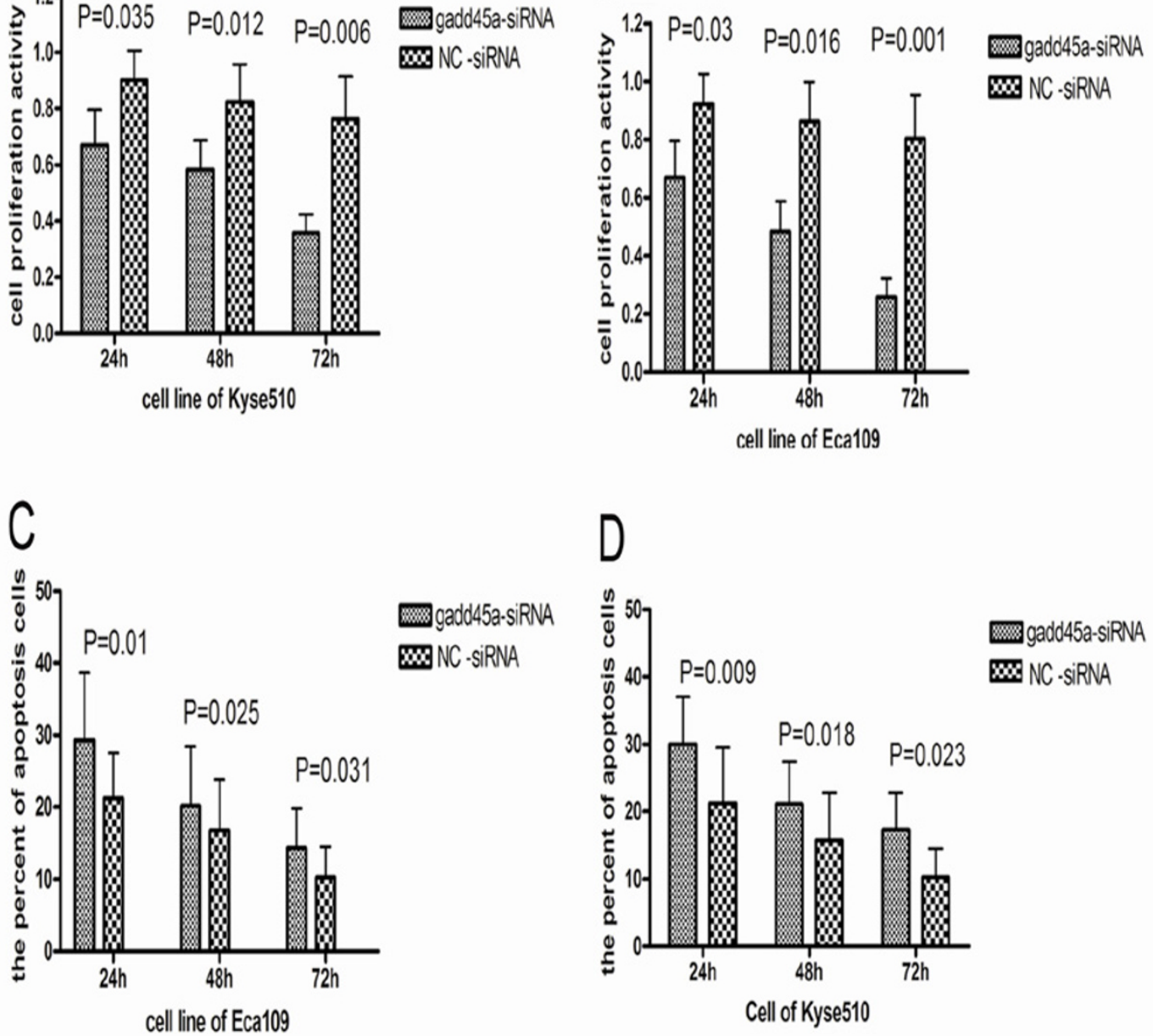

Figure $5 \mathrm{~A}$ and B show the drug sensitivity of ECA109 and KYSE510 after transfection with siRNA-GADD45 $\boldsymbol{\alpha}$. ECA109 and KYSE510 cells in NC-siRNA group were more sensitive to DDP than that in two GADD45 $\alpha$-siRNA groups at $24 \mathrm{~h}, 48 \mathrm{~h}$ and $72 \mathrm{~h}$ with DDP treatment. Moreover, the percent of survival cells was measured by MTT value. C and D, show that the percent of survival cells at $24 \mathrm{~h}, 48 \mathrm{~h}$ and $72 \mathrm{~h}$ with DDP treatment were degraded in two GADD45 $\alpha$-siRNA groups compared to NC-siRNA groups. 

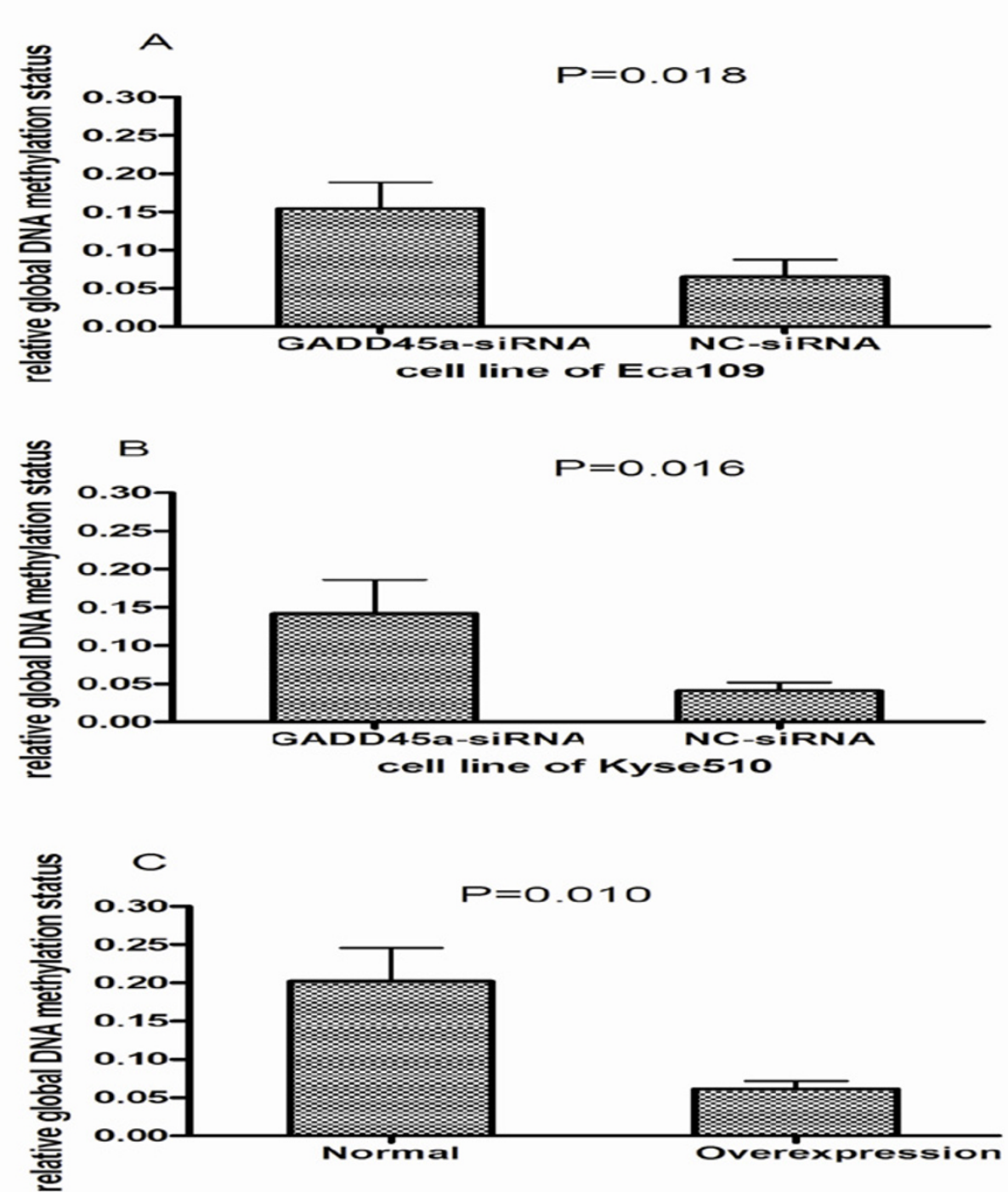

Figure 6 A and B show that the DNA global methylation level in GADD45 $\alpha$-siRNA group was increased compared with NC-siRNA cells group. $C$ show that DNA global methylation level in over expression of GADD45 $\alpha$ group was decreased compared with normal cells group.

agents[49]. Our finding showed that Eca109 and Kyse510 cells with knock-down GADD45 $\alpha$ have decreased chemotherapeutic sensitivity to DDP, suggesting GADD $45 \alpha$ may be play an important role in drug resistance of tumor cells. In next work, we will investigate the mechanisms that GADD45 $\alpha$ decreases chemotherapeutic sensitivity to DDP.

In summary, overexpression and promoter hypomethylation of GADD45 $\alpha$ gene and global DNA hypomethylation were found in ESCC tissues, which provide evidence that promoter hypomethylation may be the major mechanism for activating GADD $45 \alpha$ gene in ESCC. The function of GADD $45 \alpha$ in cell proliferation and apoptosis further demonstrated that overexpression of GADD $45 \alpha$ contributes to the development of ESCC.
However, the experiment of drug sensitivity indicated that GADD $45 \alpha$ may be a protecting factor in DDP chemotherapy.

\section{Acknowledgements}

All the experiment was made in epigenetic laboratory and biomaterial laboratory of the second Xiang Ya hospital. Thank all the staff of laboratory for their help. Thank Gong ping Liang and Ye rong Hu for their help.

\section{Author details}

${ }^{1}$ Department of cardiothoracic Surgery, Second Xiangya Hospital of Central South University, Changsha, Hunan, PR China. ${ }^{2}$ Hunan Key Laboratory of Medical Epigenomics, Department of Dermatology, Second Xiangya Hospital of Central South University, Changsha, Hunan, PR China. ${ }^{3}$ Department of cardiothoracic Surgery, Xiangya Hospital of Central South University, Changsha, Hunan, PR China. ${ }^{4}$ Department of cardiothoracic Surgery, Third Xiangya Hospital of Central South University, Changsha, Hunan, PR China. 


\section{Authors' contributions}

BXW made all the experiment and wrote the manuscript. BIY and CC devised the experiment. BH, WxZ and YP made statistical data. MZ, ZkX and JqT made language amend of the manuscript. NY and XmZ checked and approved the manuscript. All authors read and approved the final manuscript.

\section{Authors' information}

Bao xiang Wang: A medical Doctoral student in the second Xiang Ya hospital, majors in thoracic and cardiovascular surgery. He has worked for three years as a cardiovascular surgery doctor.

\section{Competing interests}

The authors declare that they have no competing interests.

Received: 23 November 2011 Accepted: 8 February 2012 Published: 8 February 2012

\section{References}

1. Cortellino S, XU J, Sannai M, Moore R, Caretti E, Cigliano A, Le CM, Devarajan K, Wessels A, Soprano D, Abramowitz LK, Bartolomei MS, Rambow F, Bassi MR, Bruno T, Fanciulli M, Renner C, Klein-Szanto AJ, Matsumoto Y, Kobi D, Davidson I, Alberti C, Larue L, Bellacosa A: Thymine DNA glycosylase is essential for active DNA demethylation by linked deamination-base excision repair. Cell 2011, 146(1):67-79.

2. Kamangar F, Dores GM, Anderson WF: Patterns of cancer incidence, mortality, and prevalence across five continents: defining priorities to reduce cancer disparities in different geographic regions of the world. J Clin Oncol 2006, 24(14):2137-2150.

3. Enzinger PC, Mayer RJ: Esophageal cancer. N Engl J Med 2003, 349(23):2241-2252

4. Morita M, Kuwano H, Ohno S, Sugimachi K, Seo Y, Tomoda H, Furusawa M, Nakashima T: Multiple occurrence of carcinoma in the upper aerodigestive tract associated with esophageal cancer: reference to smoking, drinking and family history. Int J Cancer 1994, 58(2):207-210.

5. Zhang QX, Feng R, Zhang W, Ding Y, Yang JY, Liu GH: Role of stressactivated MAP kinase P38 in cisplatin- and DTT-induced apoptosis of the esophageal carcinoma cell line Eca109. World J Gastroenterol 2005, 11(29):4451-4456.

6. Wang CC, Mao WM, LING ZQ: [Expression of DNA methylation of APC in peripheral blood and tumor tissue in patients with esophageal squamous cell carcinoma]. Zhonghua Wei Chang Wai Ke Za Zhi 2011, 14(9):719-722.

7. Lima SC, Hernandez-Vargas H, Simao T, Durand G, Kruel CD, Le CalvezKelm F, Ribeiro PL, Herceg Z: Identification of a DNA methylome signature of esophageal squamous cell carcinoma and potential epigenetic biomarkers. Epigenetics 2011, 6(10):1217-1227.

8. Toh Y, Oki E, Ohgaki K, Sakamoto Y, Ito S, Egashira A, Saeki H, Kakeji Y, Morita M, Sakaguchi Y, Okamura T, Maehara Y: Alcohol drinking, cigarette smoking, and the development of squamous cell carcinoma of the esophagus: molecular mechanisms of carcinogenesis. Int I Clin Oncol 2010, 15(2):135-44.

9. Silveira AP, Da SMF, Aoki S, Yamasaki LH, Rahal P, Silva AE: Gene mutations and polymorphisms of TP53 and FHIT in chronic esophagitis and esophageal carcinoma. Anticancer Res 2011, 31(5):1685-1690.

10. Li X, Lin R, Li J: Epigenetic silencing of MicroRNA-375 regulates PDK1 expression in esophageal cancer. Dig Dis Sci 2011, 56(10):2849-2856.

11. Ling ZQ, Li P, Ge MH, Zhao X, Hu FJ, Fang XH, Dong ZM, Mao WM: Hypermethylation-modulated down-regulation of $\mathrm{CDH} 1$ expression contributes to the progression of esophageal cancer. Int J Mol Med 2011, 27(5):625-635.

12. Qifeng S, Bo C, Xingtao J, Chuanliang P, Xiaogang Z: Methylation of the promoter of human leukocyte antigen class I in human esophageal squamous cell carcinoma and its histopathological characteristics. J Thorac Cardiovasc Surg 2011, 141(3):808-814.

13. Chang X, Yamashita K, Sidransky D, Kim MS: Promoter methylation of heat shock protein B2 in human esophageal squamous cell carcinoma. Int J Oncol 2011, 38(4):1129-1135.

14. Cortellino S, Xu J, Sannai M, Moore R, Caretti E, Cigliano A, Le Coz M, Devarajan K, Wessels A, Soprano D, Abramowitz LK, Bartolomei MS, Rambow F, Bassi MR, Bruno T, Fanciulli M, Renner C, Klein-Szanto AJ,
Matsumoto Y, Kobi D, Davidson I, Alberti C, Larue L, Bellacosa A: Thymine DNA glycosylase is essential for active DNA demethylation by linked deamination-base excision repair. Cell 2011, 146(1):67-79.

15. Cullis CA: The use of DNA polymorphisms in genetic mapping. Genet Eng (N Y) 2002, 24:179-189.

16. Hollander MC, Sheikh MS, Bulavin DV, Lundgren K, Augeri-Henmueller L, Shehee R, Molinaro TA, Kim KE, Tolosa E, Ashwell JD, Rosenberg MP, Zhan Q, Fernandez-Salguero PM, Morgan WF, Deng CX, Fornace AJ Jr: Genomic instability in Gadd45a-deficient mice. Nat Genet 1999, 23(2):176-184

17. Hildesheim J, Bulavin DV, Anver MR, Alvord WG, Hollander MC, Vardanian L, Fornace AJ Jr: Gadd45a protects against UV irradiation-induced skin tumors, and promotes apoptosis and stress signaling via MAPK and p53. Cancer Res 2002, 62(24):7305-7315.

18. Jin $\mathrm{S}$, Tong T, Fan W, Fan F, Antinore MJ, Zhu X, Mazzacurati L, Li X, Petrik KL, Rajasekaran B, Wu M, Zhan Q: GADD45-induced cell cycle G2-M arrest associates with altered subcellular distribution of cyclin B1 and is independent of p38 kinase activity. Oncogene 2002, 21(57):8696-8704.

19. Barreto G, Schafer A, Marhold J, Stach D, Swaminathan SK, Handa V, Doderlein G, Maltry N, Wu W, Lyko F, Niehrs C: Gadd45a promotes epigenetic gene activation by repair-mediated DNA demethylation. Nature 2007, 445(7128):671-675.

20. Feinberg AP, Vogelstein B: Hypomethylation distinguishes genes of some human cancers from their normal counterparts. Nature 1983, 301(5895):89-92

21. Gaudet F, Hodgson JG, Eden A, Jackson-Grusby L, Dausman J, Gray JW, Leonhardt $\mathrm{H}$, Jaenisch R: Induction of tumors in mice by genomic hypomethylation. Science 2003, 300(5618):489-492.

22. Huang SD, Yuan Y, Liu XH, Gong DJ, Bai CG, Wang F, Luo JH, Xu ZY: Selfrenewal and chemotherapy resistance of p75NTR positive cells in esophageal squamous cell carcinomas. BMC Cancer 2009, 9:9.

23. Jin $\mathrm{S}$, Antinore $M J$, Lung FD, Dong $X$, Zhao $H$, Fan F, Colchagie $A B$, Blanck P, Roller PP, Fornace AJ Jr, Zhan Q: The GADD45 inhibition of Cdc2 kinase correlates with GADD45-mediated growth suppression. J Biol Chem 2000, 275(22):16602-16608.

24. Zhan Q, Jin S, Ng B, Plisket J, Shangary S, Rathi A, Brown KD, Baskaran R: Caspase-3 mediated cleavage of BRCA1 during UV-induced apoptosis. Oncogene 2002, 21(34):5335-5345.

25. Salvador JM, Hollander MC, Nguyen AT, Kopp JB, Barisoni L, Moore JK, Ashwell JD, Fornace AJ Jr: Mice lacking the p53-effector gene Gadd45a develop a lupus-like syndrome. Immunity 2002, 16(4):499-508.

26. Hollander MC, Kovalsky O, Salvador JM, Kim KE, Patterson AD, Haines DC, Fornace AJ Jr: Dimethylbenzanthracene carcinogenesis in Gadd45a-null mice is associated with decreased DNA repair and increased mutation frequency. Cancer Res 2001, 61(6):2487-2491.

27. Smith ML, Kontny HU, Zhan Q, Sreenath A, O'Connor PM, Fornace AJ Jr: Antisense GADD45 expression results in decreased DNA repair and sensitizes cells to u.v.-irradiation or cisplatin. Oncogene 1996, 13(10):2255-2263.

28. Tront JS, Huang Y, Fornace AJ Jr, Hoffman B, Liebermann DA: Gadd45a functions as a promoter or suppressor of breast cancer dependent on the oncogenic stress. Cancer Res 2010, 70(23):9671-9681.

29. Zhang XY, Qu X, Wang CQ, Zhou CJ, Liu GX, Wei FC, Sun SZ: Overexpression of Gadd45a enhances radiotherapy efficacy in human Tca8113 cell line. Acta Pharmacol Sin 2011, 32(2):253-258.

30. Carrier F, Georgel PT, Pourquier P, Blake M, Kontny HU, Antinore MJ, Gariboldi M, Myers TG, Weinstein JN, Pommier Y, Fornace AJ Jr: Gadd45, a p53-responsive stress protein, modifies DNA accessibility on damaged chromatin. Mol Cell Biol 1999, 19(3):1673-1685.

31. Reinhardt HC, Hasskamp P, Schmedding I, Morandell S, van Vugt MA, Wang X, Linding R, Ong SE, Weaver D, Carr SA, Yaffe MB: DNA damage activates a spatially distinct late cytoplasmic cell-cycle checkpoint network controlled by MK2-mediated RNA stabilization. Mol Cell 2010, 40(1):34-49.

32. Zhan Q: Gadd45a, a p53- and BRCA1-regulated stress protein, in cellular response to DNA damage. Mutat Res 2005, 569(1-2):133-143.

33. Fornace AJ Jr, Jackman J, Hollander MC, Hoffman-Liebermann B, Liebermann DA: Genotoxic-stress-response genes and growth-arrest genes gadd, MyD, and other genes induced by treatments eliciting growth arrest. Ann N Y Acad Sci 1992, 663:139-153. 
34. Fornace AJ Jr, Nebert DW, Hollander M, Luethy JD, Papathanasiou M, Fargnoli J, Holbrook NJ: Mammalian genes coordinately regulated by growth arrest signals and DNA-damaging agents. Mol Cell Biol 1989, 9(10):4196-4203.

35. Ling ZQ, Li P, Ge MH, Hu FJ, Fang XH, Dong ZM, Mao WM: Aberrant Methylation of Different DNA Repair Genes Demonstrates Distinct Prognostic Value for Esophageal Cancer. Dig Dis Sci 2011, 56(10):2992-3004.

36. Tront JS, Hoffman B, Liebermann DA: Gadd45a suppresses Ras-driven mammary tumorigenesis by activation of c-Jun $\mathrm{NH2}$-terminal kinase and p38 stress signaling resulting in apoptosis and senescence. Cancer Res 2006, 66(17):8448-8454.

37. Pogribny IP, Beland FA: DNA hypomethylation in the origin and pathogenesis of human diseases. Cell Mol Life Sci 2009, 66(14):2249-2261.

38. Wilson AS, Power BE, Molloy PL: DNA hypomethylation and human diseases. Biochim Biophys Acta 2007, 1775(1):138-162.

39. Hsiung DT, Marsit CJ, Houseman EA, Eddy K, Furniss CS, McClean MD, Kelsey KT: Global DNA methylation level in whole blood as a biomarker in head and neck squamous cell carcinoma. Cancer Epidemiol Biomarkers Prev 2007, 16(1):108-114.

40. Chen C, Yin N, Yin B, Lu Q: DNA methylation in thoracic neoplasms. Cancer Lett 2011, 301(1):7-16.

41. Rodriguez J, Frigola J, Vendrell E, Risques RA, Fraga MF, Morales $C$ Moreno V, Esteller M, Capella G, Ribas M, Peinado MA: Chromosomal instability correlates with genome-wide DNA demethylation in human primary colorectal cancers. Cancer Res 2006, 66(17):8462-9468.

42. Ehrlich M: DNA methylation in cancer: too much, but also too little. Oncogene 2002, 21(35):5400-5413.

43. Takekawa M, Saito H: A family of stress-inducible GADD45-like proteins mediate activation of the stress-responsive MTK1/MEKK4 MAPKKK. Cell 1998, 95(4):521-530.

44. Harkin DP, Bean JM, Miklos D, Song YH, Truong VB, Englert C, Christians FC, Ellisen LW, Maheswaran S, Oliner JD, Haber DA: Induction of GADD45 and JNK/SAPK-dependent apoptosis following inducible expression of BRCA1. Cell 1999, 97(5):575-586.

45. Kuwahara A, Yamamori M, Kadoyama K, Nishiguchi K, Nakamura T, Miki I, Tamura T, Okuno T, Omatsu H, Sakaeda T: Effects of plasma concentrations of 5-fluorouracil on long-term survival after treatment with a definitive 5-fluorouracil/cisplatin-based chemoradiotherapy in Japanese patients with esophageal squamous cell carcinoma. J Exp Clin Cancer Res 2011, 30(1):94.

46. Koo DH, Park SI, Kim YH, Kim JH, Jung HY, Lee GH, Choi KD, Song HJ, Song HY, Shin JH, Cho KJ, Yoon DH, Kim SB: Phase II study of use of a single cycle of induction chemotherapy and concurrent chemoradiotherapy containing capecitabine/cisplatin followed by surgery for patients with resectable esophageal squamous cell carcinoma: long-term follow-up data. Cancer Chemother Pharmacol 2011, 28(11):1750-1755, 2011

47. Yokota T, Hatooka S, Ura T, Abe T, Takahari D, Shitara K, Nomura M, Kondo C, Mizota A, Yatabe Y, Shinoda M, Muro K: Docetaxel plus 5Fluorouracil and Cisplatin (DCF) Induction Chemotherapy for Locally Advanced Borderline-resectable T4 Esophageal Cancer. Anticancer Res 2011, 31(10):3535-3541.

48. Piacentini P, Durante E, Trolese A, Mercanti A, Bonetti A: Weekly Taxotere and cisplatin with continuous-infusion 5-fluoruracil for the treatment of advanced gastric and esophageal cancer: a prospective, observational, single-institution experience. Gastric Cancer 2012, 15(1):106-10.

49. Gopisetty G, Ramachandran K, Singal R: DNA methylation and apoptosis. Mol Immunol 2006, 43(11):1729-1740.

\section{doi:10.1186/1756-9966-31-11}

Cite this article as: Wang et al:: Overexpression of DNA damageinduced $45 \alpha$ gene contributes to esophageal squamous cell cancer by promoter hypomethylation. Journal of Experimental \& Clinical Cancer Research 2012 31:11.

\section{Submit your next manuscript to BioMed Central and take full advantage of:}

- Convenient online submission

- Thorough peer review

- No space constraints or color figure charges

- Immediate publication on acceptance

- Inclusion in PubMed, CAS, Scopus and Google Scholar

- Research which is freely available for redistribution

Submit your manuscript at www.biomedcentral.com/submit
C Biomed Central 